\title{
Sternal rub causing presternal abrasion in a patient with capsuloganglionic haemorrhage
}

\author{
Ravikiran Naalla, ${ }^{1}$ Prathusha Chitirala, ${ }^{2}$ Praveen Chittaluru, ${ }^{3}$ Viswanath Atreyapurapu ${ }^{1}$
}

${ }^{1}$ Department of General Surgery, Kasturba Medical College, Manipal, Karnataka, India

${ }^{2}$ Sri Venkateswara Medical College, Tirupati, Andhra Pradesh, India

${ }^{3}$ Kasturba Medical College,

Manipal, Karnataka, India

Correspondence to Dr Ravikiran Naalla, ravi_2488@yahoo.co.in

Accepted 13 March 2014

\section{(a) CrossMark}

To cite: Naalla $R$, Chitirala P, Chittaluru P, et al. BMJ Case Rep Published online: [please include Day Month Year] doi:10.1136/bcr-2014204028

\section{DESCRIPTION}

A 50-year-old man with a history of hypertension was diagnosed with a left capsuloganglionic haemorrhage and he underwent right frontal burr hole and external ventricular drainage for ongoing hydrocephalus. He was referred to our tertiary care hospital for further management after 6 days of treatment. His Glasgow Coma Scale (GCS) at first visit to the referring hospital was E1, M3, V1. His GCS at admission to our hospital was E1, M1, VT, and he had a healing abrasion over the presternal area measuring $7 \mathrm{~cm}$ in length and $1 \mathrm{~cm}$ maximum breadth (figure 1). We contacted the referring hospital regarding the abrasion and were informed that it was a sternal rub-induced abrasion.

Pain stimulus is a technique used by medical personnel for assessing the consciousness level of a person who is not responding to normal interaction, voice commands or gentle physical stimuli. It forms one part of a number of neurological assessments including GCS. Pain stimulus can be applied either centrally or peripherally; the benefits and drawbacks of each method have to be considered for the appropriate clinical scenario. Trapezius squeeze, mandibular pressure, supraorbital pressure, sternal rub are four commonly used central stimuli. Central stimuli should always be used when attempting to assess if the patient responds to

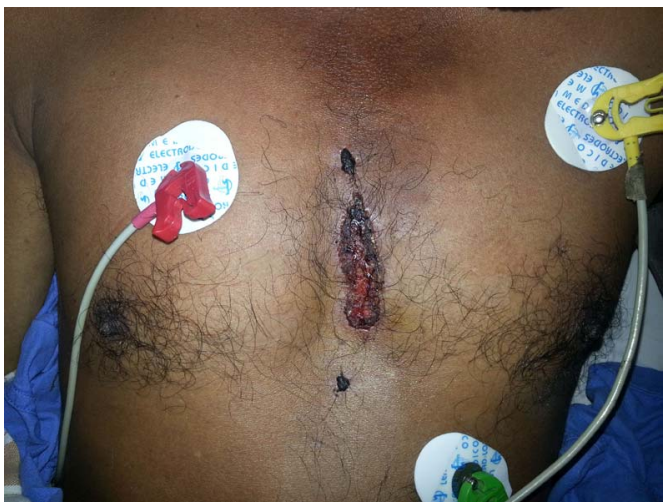

Figure 1 Photograph showing healing abrasion over the presternal area. painful stimuli. ${ }^{1}$ Peripheral stimuli are generally applied to the limbs. Central stimuli need to be applied for at least 15 and potentially up to $30 \mathrm{~s}$ in order for the clinician to accurately assess their efficacy. ${ }^{1}$ Sternal rub is known for bruising in fair-skinned people hence its use has been discouraged. $^{2}$ Presternal abrasion is a preventable complication. Skin over the presternum has to be checked before each assessment for any signs of bruisability or damage. Other methods of central stimuli should be used for neurological assessment once skin damage is observed. Medical care personnel should take this into account in their routine day-to-day practice.

\section{Learning points}

Sternal rub is a commonly used method of assessing response to painful stimuli in assessing the neurological status of an individual.

- Presternal abrasion is a preventable complication. Skin over the presternum has to be checked before each assessment for any signs of bruisability or damage.

- Other methods of central stimuli should be used for neurological assessment once skin damage is imminent.

Contributors RN participated in image and data collection. PC participated in proofreading and editing. VA participated in proof reading.

Competing interests None.

Patient consent Obtained.

Provenance and peer review Not commissioned; externally pee reviewed.

\section{REFERENCES}

1 Mistovich JJ, Krost W, Limmer DD. Beyond the basics: patient assessment. Emerg Med Serv 2006;35:72-7; quiz 78-9.

2 Middleton PM. Practical use of the Glasgow Coma Scale; a comprehensive narrative review of GCS methodology. Australas Emerg Nurs J 2012;15:170-83. 


\section{Images in...}

Copyright 2014 BMJ Publishing Group. All rights reserved. For permission to reuse any of this content visit http://group.bmj.com/group/rights-licensing/permissions.

BMJ Case Report Fellows may re-use this article for personal use and teaching without any further permission.

Become a Fellow of BMJ Case Reports today and you can:

- Submit as many cases as you like

- Enjoy fast sympathetic peer review and rapid publication of accepted articles

- Access all the published articles

- Re-use any of the published material for personal use and teaching without further permission

For information on Institutional Fellowships contact consortiasales@bmjgroup.com

Visit casereports.bmj.com for more articles like this and to become a Fellow 